\title{
Studies of performance and emission characteristics of compressed natural gas fuelled S.I. engine and developing CNG conversion kit
}

\author{
Joyanta Paul $^{1}$, Md. Arafat Hossain ${ }^{2}$, Shubhra Kanti Das ${ }^{3}$, Rezaur Rahman ${ }^{4}$

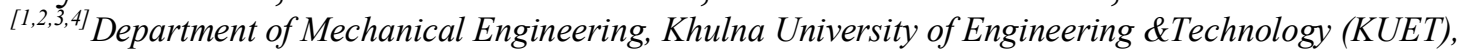
Khulna-9203, BANGLADESH

\begin{abstract}
In Bangladesh, petrol, diesel and octane are conventionally used as an engine fuel. Petrol and octane are used only transport sector. Diesel is used in transport, agriculture and power generation among them $45 \%$ of diesel is consumed in transport sector. Total demand of liquid fuel is rising day by day. The country has no natural sources of liquid fuels. As a result a huge amount of money spent for importing fuel from abroad. This expenditure will be massive amount within a few years. The gas could be compressed natural gas $(C N G)$ or bio methane. The advantage is that this reduces fuel costs and when local bio methane is used, it also contributes to the use of a more sustainable fuel supply.

$C N G$ system suppliers are currently developing dual-fuel technology and have already converted trucks, using government grants. Furthermore, various exploratory studies into the dual-fuel principle are being conducted under contract to various municipalities in the context of sustainable transportation (fermentation of city waste to produce bio methane for use as engine fuel). According to World Health Organization (WHO), the safe limit of dust particles in the atmosphere is 40 to 80 micrograms, whereas in Dhaka city, it is 1700 to 2200 micrograms. To minimize environmental pollution in Dhaka, CNG played a vital role now a day. To use CNG on commercial basis, different programs are taken to use compressed natural gas (CNG). This program mainly concentrated on road transport. These programs cannot spread throughout the country due to some difficulties. But there is a huge potentiality in road, marine, railway and stationary engines to use $C N G$.
\end{abstract}

Keywords: SI engine, electronic conversion kit, CNG, Diesel.

\section{Introduction}

Small diesel engines, typically producing less than $20 \mathrm{hp}$, are widely used all over Bangladesh. The number of small diesel engine in operation is estimated to be about 0.7 million. The most important conventional use is in irrigation for driving Low Lift pumps and shallow tube wells in rural Bangladesh. Although electricity have reached in about $60 \%$ villages, still more that $2 / 3 \mathrm{rd}$ of the irrigation devices are still run on diesel [1]. Diesel engines have got a wide application in about 0.9 million country boat, a large proportion of which run by diesel now-a-days. [1]

Diesel fuel is the largest imported energy resource for Bangladesh. Since the requirement of octane/petrol is about 0.4 million metric tons per year, only about 0.27 million of the Diesel requirement is met by refining imported crude oil at the only refinery of the country, while the remaining Diesel needs to be imported as a finished product. Consumption can be related to small diesel engines in the applications mentioned above. [1]

Once it is clear that dual-fuel systems can be applied safely as well as environmentally friendly, the program can be wound up to make place for normal regulations. Compressed natural gas $(\mathrm{CNG})$ is a fossil fuel substitute for gasoline (petrol), diesel, or propane/LPG. CNG is made by compressing natural gas, to less than $1 \%$ of the volume it occupies at standard atmospheric pressure. CNG is used in traditional gasoline internal combustion (I.C) engine cars that have been converted into bi-fuel vehicles (gasoline/CNG).

The objectives of this project,

\section{Objective}

1. Conversion of a S.I engine to CNG fuelled engine.

2. Performance test of $\mathrm{CNG}$ and fuelled S.I engine.

3. Theoretical development of an electronic conversion kit for CNG fuelled S.I engine.

\section{Components Of Engine Generator}

In addition to the engine and generator, engine-generators generally include a fuel supply, a constant engine speed regulator (governor) and a generator voltage regulator, cooling and exhaust systems, and lubrication system. Units larger than about $1 \mathrm{~kW}$ rating often have a battery and electric starter motor; very large 
units may start with compressed air either to an air driven starter motor or introduced directly to the engine cylinders to initiate engine rotation. Standby power generating units often include an automatic starting system and a transfer swit to disconnect the load from the utility power source when there is a power failure and connect it to the generator. [2]

\section{Cng Equivalent To Gasoline Diesel Cng}

The CNG can be considered as equivalent to the other existing fuel and comparison are as follows:

Comparison:
1. $1 \mathrm{~kg} \mathrm{CNG}=1.4 \mathrm{~m} 3 \mathrm{CNG}$
2. $1 \mathrm{~L}$ petrol $=1.0 \mathrm{~m} 3 \mathrm{CNG}$
3. $1 \mathrm{~L}$ diesel $=1.2 \mathrm{~m} 3 \mathrm{CNG}$
4. $1 \mathrm{~L} \mathrm{LPG}=0.8 \mathrm{~m} 3 \mathrm{CNG}[7]$

\section{Types Of Conversion}

Most of the natural gas fuelled vehicles are conversions of existing gasoline or diesel vehicles. In the case of spark-ignition engines, these conversions are generally bi-fuel where the driver can switch from natural gas to gasoline and vice versa during engine operation; for compression-ignition engines available options include dual-fuel conversions, where the engine runs with a mixture of natural gas and diesel but auto ignited through diesel only, and spark ignition conversions.[3]

1. Bi-fuel Gasoline Conversion

2. Diesel Conversion

\section{Components Required For Conversion}

The installation of the gas equipment comprises the following parts:

1. Pressure Regulator (Reducer)

2. Gas/Air Mixer (or Electronic Fuel Injector)

3. CNG Filling valve

4. High-pressure Lines

5. CNG Tank and Valve

6. Gasoline/CNG Selector Switch

7. vii. Pressure Gauge

8. Gasoline Electro valve

9. Low pressure Pipe

\section{Components Of Cng Kits}

1. Pressure Regulator (Pressure Reducer).

2. Filling valve.

3. High pressure pipe:

4. CNG Cylinder.

5. Main Shut off Valve:

6. Adjusting Resistor Screw:

7. Petrol I CNG Selector switch.

8. Gasoline Solenoid valve.

9. Pressure Gauge

VIII. Picture Layout Of Conversion System

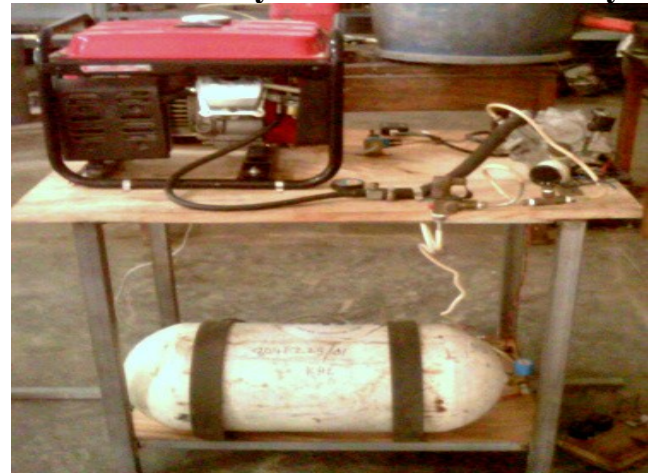

Figure:1 Layout of Conversion System

IX. Checking Required Before Conversion 
There are a few checks that need to be performed before the engine enters the installation workshop for conversion. The ignition system: spark plugs spark plug cables, contact points, condenser, ignition coil, ignition plate and distributor. The faulty state of any of these parts will cause a poor ignition spark, thus hindering the good functioning of the equipment. The battery must provide 12 volts of power to the pressure regulator so that its electro valve will open properly when the engine is operating on gas. [4]

\section{Performance Test}

A. Exhaust Gas Components Analysis Using Orsat Apparatus

Different components present in the exhaust gas can be found by using Orsat apparatus with the following equation.

$\mathrm{CxH} y+\mathrm{BO}_{2}+\mathrm{CN} 2=\mathrm{aCO}_{2}+\mathrm{bO}_{2}+\mathrm{c} \mathrm{N}_{2}+\mathrm{dCO}+\mathrm{e} \mathrm{H}_{2} \mathrm{O}$

Amount of oxygen present in the air, $\mathrm{O}_{2}=\mathrm{N}_{2} / 3.76$

Equipment \& Chemical Required:

1. Orsat gas analyzer.

2. ampling bottle with exhaust gas.

3. KOH solution.

4. Pyrogallic acid and $\mathrm{KOH}$ solution.

5. $\mathrm{Cu}_{2} \mathrm{O}$ and concentrated $\mathrm{HCl}$

\begin{tabular}{|c|c|c|c|c|c|c|c|c|}
\hline SL & Load & $\begin{array}{c}\text { Total } \\
\text { volume } \\
\text { of } \\
\text { sample } \\
\text { gas } \\
\text { V in } \\
\text { after } \\
\text { thring } \\
\text { though } \\
\text { flask, A } \\
\text { VA in } \\
\text { c.c } \\
\text { c. c }\end{array}$ & $\begin{array}{c}\text { Volume } \\
\text { passing } \\
\text { through } \\
\text { flask, B } \\
\text { VB in } \\
\text { c.c } \\
\text { (watt) }\end{array}$ & $\begin{array}{c}\text { Volume } \\
\text { after } \\
\text { thring } \\
\text { flask, C } \\
\text { VC in } \\
\text { c.c }\end{array}$ & $\begin{array}{c}\text { Volume } \\
\text { of CO2 } \\
\text { in c.c }\end{array}$ & $\begin{array}{c}\text { Volume } \\
\text { of O2 } \\
\text { in c.c }\end{array}$ & $\begin{array}{c}\text { Volume } \\
\text { of CO } \\
\text { in c.c }\end{array}$ \\
\hline 1 & $\begin{array}{c}\text { No } \\
\text { load }\end{array}$ & 100 & 92 & 90 & 89 & 8 & 2 & 1 \\
\hline 2 & 200 & 100 & 92 & 91 & 90 & 8 & 1 & 1 \\
\hline 3 & 400 & 100 & 94 & 91 & - & 6 & 2 & - \\
\hline
\end{tabular}

Table 1: Exhaust gas analysis for Petrol

\begin{tabular}{|c|c|c|c|c|c|c|c|c|}
\hline SL & $\begin{array}{l}\text { Load } \\
\text { (watt) }\end{array}$ & 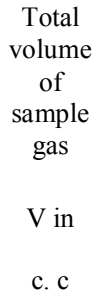 & $\begin{array}{l}\text { Volume } \\
\text { after } \\
\text { passing } \\
\text { through } \\
\text { flask, A } \\
\text { VA in } \\
\text { c.c }\end{array}$ & $\begin{array}{c}\text { Volume } \\
\text { after } \\
\text { passing } \\
\text { through } \\
\text { flask, B } \\
\text { VB in } \\
\text { c.c }\end{array}$ & $\begin{array}{c}\text { Volume } \\
\text { after } \\
\text { passing } \\
\text { through } \\
\text { flask, C } \\
\text { VC in } \\
\text { c.c }\end{array}$ & $\begin{array}{c}\text { Volume } \\
\text { of CO2 } \\
\text { in c.c }\end{array}$ & $\begin{array}{c}\text { Volume } \\
\text { of } \mathrm{O} 2 \\
\text { in c.c }\end{array}$ & $\begin{array}{c}\text { Volume } \\
\text { of CO } \\
\text { in c.c }\end{array}$ \\
\hline 1 & $\begin{array}{c}\text { No } \\
\text { load }\end{array}$ & 100 & 95 & 93 & - & 5 & 2 & - \\
\hline 2 & 200 & 100 & 95 & 94 & - & 5 & 1 & - \\
\hline 3 & 400 & 100 & 96 & 95 & - & 4 & 1 & - \\
\hline
\end{tabular}

Table 2: Exhaust gas analysis for $\mathrm{CNG}$

Temperature of exhaust gas varies with the change of load of generator and the change of RPM. The exhaust gas temperature of petrol running condition and the CNG running condition is different for variable loads. Temperature also depends on the generator condition.

\begin{tabular}{|l|l|l|}
\hline $\begin{array}{l}\text { No of } \\
\text { Observation }\end{array}$ & $\begin{array}{l}\text { Load } \\
\text { (watt) }\end{array}$ & Temperature $^{\circ} \mathrm{C}$ \\
\hline
\end{tabular}




\begin{tabular}{|l|l|l|}
1 & $\begin{array}{l}\text { No } \\
\text { load }\end{array}$ & 284 \\
\hline 2 & 200 & 299 \\
\hline 3 & 400 & 320 \\
\hline 4 & 600 & 327 \\
\hline
\end{tabular}

Table 3: Exhaust Gas Temperature for Petrol

\begin{tabular}{|l|l|l|}
\hline $\begin{array}{l}\text { No observation } \\
\text { Ob }\end{array}$ & $\begin{array}{l}\text { Load } \\
\text { (watt) }\end{array}$ & Temperature $^{\circ} \mathrm{C}$ \\
\hline 1 & $\begin{array}{l}\text { No } \\
\text { load }\end{array}$ & 359 \\
\hline 2 & 200 & 380 \\
\hline 3 & 400 & 385 \\
\hline 4 & 600 & 382 \\
\hline
\end{tabular}

Table 4 Exhaust Gas Temperature for $\mathrm{CNG}$

\section{B. Speed Measurement for Various Loads}

Speed of the generator change with the change of load for both petrol and CNG fuelled engine. Digital Tachometer have used for the measurement of speed. Load has given with electric bulb (200 watt, 4 pieces).

\begin{tabular}{|l|l|l|}
\hline $\begin{array}{l}\text { No of } \\
\text { Observation }\end{array}$ & Load (watt) & $\begin{array}{l}\text { Speed } \\
\text { (r.p.m) }\end{array}$ \\
\hline 1 & No load & 1653 \\
\hline 2 & 200 & 1520 \\
\hline 3 & 400 & 1234 \\
\hline 4 & 600 & 985 \\
\hline
\end{tabular}

Table 5: Speed Variation for Petrol

\begin{tabular}{|l|l|l|}
\hline $\begin{array}{l}\text { No observation } \\
\text { Of }\end{array}$ & $\begin{array}{l}\text { Load } \\
\text { (watt) }\end{array}$ & $\begin{array}{l}\text { Speed } \\
\text { (r.p.m) }\end{array}$ \\
\hline 1 & No load & 1814 \\
\hline 2 & 200 & 1675 \\
\hline 3 & 400 & 1535 \\
\hline 4 & 600 & 1290 \\
\hline
\end{tabular}

Table 6: Speed Variation for CNG

\section{Performance Comparison between petrol and CNG Generator}

$\mathrm{CNG}$ reduces emissions of harmful gases like carbon monoxide $(\mathrm{CO})$, carbon dioxide $\left(\mathrm{CO}_{2}\right)$ and nitrogen oxide. Moreover, burning of $\mathrm{CNG}$ expels lower amounts of carcinogenic particles into the air. Burning gasoline on the other hand produces large amounts of $\mathrm{CO}$ and $\mathrm{CO}_{2}$ which leads to the greenhouse effect, commonly known as global warming. Exhaust gas temperature of CNG is higher than the petrol in the engine. In comparison curve show that the temperature for both petrol and $\mathrm{CNG}$ increase with load at certain limit and then fall. 


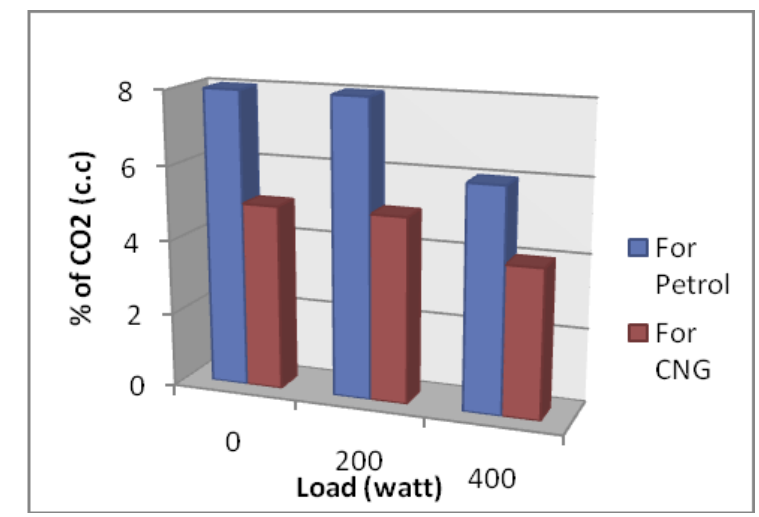

Figure 2. Percentage of $\mathrm{CO}_{2}$ verses load diagram.

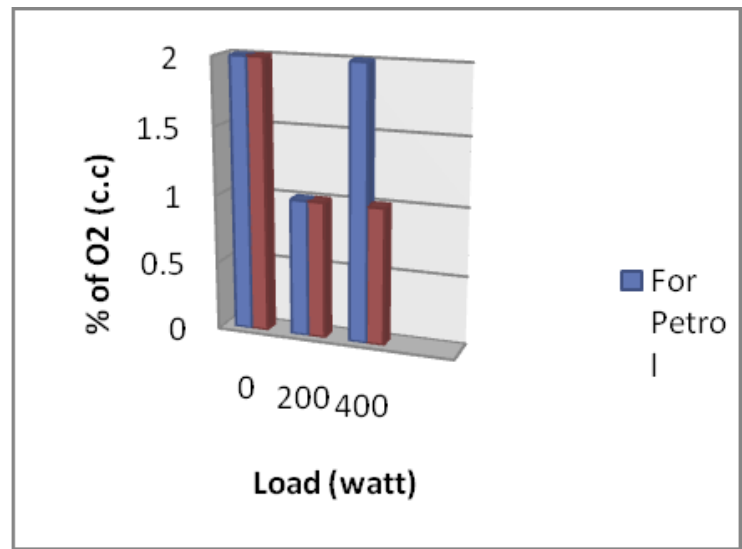

Figure 3. Percentage of $\mathrm{O}_{2}$ verses load diagram.

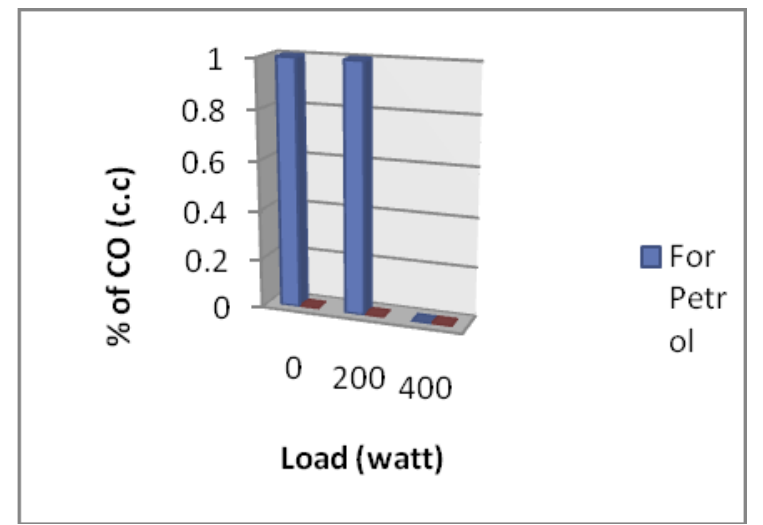

Figure 4. Percentage of CO verses load diagram.

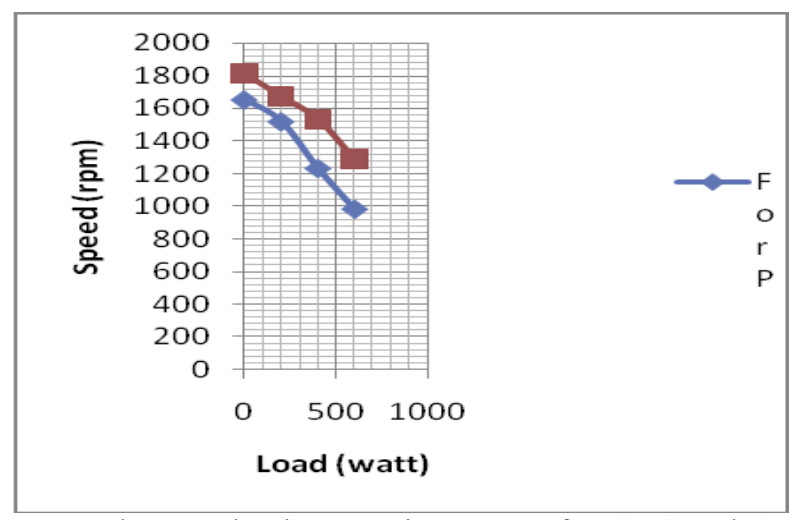

Figure 5. Speed verses load comparison curve for $\mathrm{CNG}$ and S.I engine. 


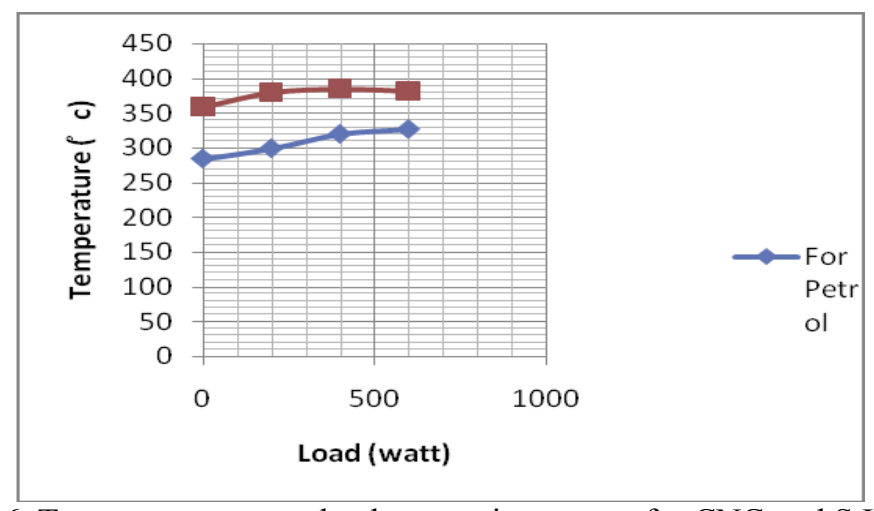

Figure 6. Temperature verses load comparison curve for CNG and S.I engine.

\section{Controlled Cng Injection By Microcontroller}

In this technique, natural gas is introduced into the cylinder through a specially designed gas injector. Electronically controlled Units interface via software with existing engine fuel management system that allows the two computers to communicate. In such system, the gas control unit commands the gas controller and issues a request for a gas pilot injection of a specific quantity at a specific time. Simultaneously it sends a signal to the natural gas injectors to inject an appropriate quantity of natural gas into the cylinders. This quantity is calculated in real time through existing conditions and is based on factor such as manifold pressure, charge air temperature, gas pressure, gas temperature to provide the best combination of emissions and efficiency.[5]

The speed variation depends on the time of CNG input in the engine cylinder. So the time of CNG injection should be controlled. This control system can be developed by the microcontroller. The converted engine could be run either petrol or in gas. But the petrol is needed in the initial starting of the engine; it is the main drawback of carburetor petrol engine because the ignition temperature of CNG is higher than the petrol engine. It could be overcome by using high voltage ignition coil. It was very difficult to determine the actual speed of the engine generator in different load because of its compact casing. Analysis of the exhaust gas was not so easy because all the components cannot found by one process, only three components are found by using Orsat apparatus. Actual time setting depends on the design of the injector nozzle. If the nozzle diameter is small, then the opening time will be long.

\section{Injector Nozzle Design}

The main design consideration of an injector nozzle is to properly design its diameter with respect of the flow rate of fuel. Injector nozzle can be designed separately for different speed of engine. The size of injector nozzle diameter depends on the swept volume and the speed of the engine generator. But in this control system single nozzle with different opening time controlled by microcontroller have used.[6]

\section{Results}

$>$ In exhaust gas analysis for petrol and for $\mathrm{CNG}$, maximum $\mathrm{CO}_{2}$ is $8 \%$ and $5 \%$ respectively, reduction of $\mathrm{CO}_{2}$ is $20 \%-30 \%$.

$>$ In starting condition for petrol $\mathrm{CO}$ is hardly $1 \%$ and for CNG negligible amount is found.

$>$ Maximum exhaust temperature in petrol running condition is $327^{\circ} \mathrm{C}$ and in $\mathrm{CNG}$ running condition is $385^{\circ} \mathrm{c}$. Exhaust gas temperature difference of CNG running generator and petrol running generator is near $80^{\circ} \mathrm{c}$. Temperature increase with the increase of load at a certain limit, then temperature fall. Temperature verses load curve show the temperature increase and fall with the variation of load for both CNG and petrol.

$>$ However it need further study for developing conversion kit

$>$.

\section{Discussion}

CNG running condition is higher than the petrol running condition. So the cooling system of $\mathrm{CNG}$ running engine should strong.

\section{Conclusion}

The converted engine runs properly either CNG or petrol. In transport sectors use of CNG engine is rising and its popularity is growing day by day. Because of its advantage over other existing fuel, in Bangladesh CNG is available in cheaper rate and the $\mathrm{CO}_{2} \& \mathrm{CO}$ pollutant is less, for which concern it should be encouraged. Introduction of $\mathrm{CNG}$ has a definite impact on environment 
improvement. Reduction in $\mathrm{CO} 2$ shall result in reducing $10 \%$ greenhouse effect and thereby improving global warming. $\mathrm{CNG}$ is much lighter than air and disperses quickly and rises upward. Hence the chances of fire hazard are minimized. Again the Cost of CNG is less than half as compared to that of petrol for developing same amount of energy.

\section{Refenences}

[1] Weaver, C. S. and Turner, S. H., "Dual Fuel NaturalGas/DieselEnginesTechnology, Performance, and Emissions," SAE Paper 940548.

[2] Mathur, M.L. \& Sharma, R.P. , "A course in Internal Combustion Engine"; First Edition (Reprint-2003); Dhanpat Rai Publications; New Delhi.

[3]. Khurmi, R.S \& Gupta, J.K. , "A text Book of Thermal Engineering (S.I. Unit)"; First Edition (Reprint-2003); S. Chand \& Company Ltd. New Delhi

[4] "Installation Manual for CNG Kit Gasoline/CNG "; Internet Source-www.omnitekcorp.com; Omnitek Engineering Corp.1945 S. Rancho Santa Fe Rd.- San Marcos, CA 92078.

[5] Thomas, G. Advantica, Goulding J. and Munteanu, C.; NMSPU Project KTll; "Measurement, Approval and Verification of CNG Dispensers"- NWML

[6] Jeffrey, B. Gotthelf (Engineering Manager ITT Conoflow); "CNG Regulator I Fuel System Interactions "ITT Industries

[7] Internetsource-http://www.cng.czlwww.cng.en. 